\title{
Perinuclear localization of slow troponin C mRNA in muscle cells is controlled by a cis-element located at its $3^{\prime}$ untranslated region
}

\author{
KISHORE K. REDDY, FERRY M. OITOMEN, GOPAL P. PATEL, and JNANANKUR BAG \\ Department of Molecular Biology and Genetics, University of Guelph, Guelph, Ontario, N1G 2W1, Canada
}

\begin{abstract}
The process of mRNA localization within a specific cytoplasmic region is an integral aspect of the regulation of gene expression. Furthermore, colocalization of mRNAs and their respective translation products may facilitate the proper assembly of multisubunit complexes like the thick and thin filaments of muscle. This postulate was tested by investigating the cytoplasmic localization of three mRNAs-the $\alpha$-actin, slow troponin C (sTnC), and slow troponin I (sTnl), which encode different polypeptide partners of the thin filament. Using in situ hybridization we showed that all three thin filament mRNAs are localized in the perinuclear cytoplasm of cultured $\mathrm{C}_{2} \mathrm{C}_{12}$ muscle cells. Their localization differs from that of the nonmuscle $\beta$-actin mRNA, which is localized in the peripheral region of both proliferating nondifferentiated myoblasts and the differentiated myocytes. Analysis of the localization signal of the sTnC mRNA showed that a 40-nucleotide-long region of the sTnC mRNA $3^{\prime}$ UTR is sufficient to confer the perinuclear localization on a heterologous reporter $\beta$-Gal mRNA. This localization signal showed tissue specificity and worked only in the differentiated myocytes, but not in the proliferating myoblasts or in HeLa cells. The predicted secondary structure of the localization signal suggests the presence of multiple stem and loop structures in this region of the 3' UTR. Mutations within the stem region of the localization signal, which abolish the base pairing in this region, significantly reduced its perinuclear mRNA localization activity. Using UV-induced photo-cross-linking of RNA and proteins we found that a myotube-specific 42-kDa polypeptide binds to the localization signal.
\end{abstract}

Keywords: mRNA localization signal; mRNA zipcode; sTnC; slow troponin C; cardiac troponin C; 3' UTR, 3' untranslated region; myogenesis

\section{INTRODUCTION}

Sorting and targeting mRNAs into specific regions of cell cytoplasm offers a means for establishing cell polarity by asymmetric RNA and protein distributions (for reviews, see St Johnston 1995; Ross et al. 1997; Jansen 2001). In the context of embryonic development, the asymmetric distribution of maternal mRNAs play an important role (St Johnston and Nüsslein-Volhard 1992; Ding and Lipshitz 1993; Bally-Cuif et al. 1998). For example, the gurken protein localization in Drosophila oocytes is controlled by the localization of its mRNA in the perinuclear region along the

Reprint requests to: Jnanankur Bag, Department of Molecular Biology and Genetics, University of Guelph, Guelph, Ontario, N1G 2W1, Canada; e-mail: jbag@uoguelph.ca; fax: (519) 837-2075.

Article and publication are at http://www.rnajournal.org/cgi/doi/ 10.1261/rna.5460105. posterior cortex. The translation of gurken mRNA in this region transmits the gurken signal to the adjacent follicle cells to adopt a posterior fate (Gonzalez-Reyes et al. 1995). RNA localization also occurs in a variety of somatic animal cells and in yeast cells. In Saccharomyces cerevisiae, ASH 1 mRNA is localized first in the future bud site and then in the daughter cells where localized expression of the Ash 1 protein represses the $\mathrm{HO}$ endonuclease, and acts to prevent mating-type switching (Long et al. 1997; Takizawa et al. 1997). RNA localization has also been described in a variety of polarized animal cells such as neurons, oligodendrocytes, fibroblasts, and epithelial cells (for review, see Palacios and St Johnston 2001). In chicken embryonic fibroblasts (motile cells), $\beta$-actin mRNA is localized in the leading edge, whereas the $\alpha$-actin isoform and vimentin mRNAs are found in the perinuclear region in muscle cells (Lawrence and Singer 1986; Cripe et al. 1993; Kislauskis et al. 1993). 
The spatial positioning of mRNAs in the cytoplasm is a complex process that involves one or more cis elements (zipcode) and transacting factors, including cytoskeletal proteins (Kislauskis et al. 1993; Hesketh 1996; Deshler et al. 1998; Havin et al. 1998). To date, almost all mRNA localization signals in eukaryotes have been found within the $3^{\prime}$ untranslated region of the mRNA (Palacios and St Johnston 2001). However, a recent study showed that the zipcode of oskar mRNA in Drosophila oocytes is present within the first intron (Hachet and Ephrussi 2004). Therefore, properly splicing pre-mRNA may be important to the cytoplasmic destination of the processed transcript, and could act as a quality control step. The localization signal of several mRNAs including $\beta$-actin c-Fos, c-Myc, and vimentin is present within an 50-100-nt-long region in their 3' UTRs (Kislauskis et al. 1994; Veyrune et al. 1996; Bermano et al. 2001; Dalgleish et al. 2001). The precise mechanism of how the cis elements of mRNA localization work is not clear. However, several localization signal-binding proteins have been characterized (Ross et al. 1997; Zehner et al. 1997; Al-Maghrebi et al. 2002). These zipcode binding proteins are believed to interact with the proteins of cytoskeletal structures and molecular motors to deliver and anchor mRNA to its proper cytoplasmic location.

One of the best studied zipcode-binding protein is ZBP1, which binds to the $\beta$-actin mRNA localization signal. Recent studies have shown that ZBP1 binds to the $\beta$-actin pre-mRNA transcripts in the nuclei of fibroblasts, and the processed mRNA is then exported to the leading edge using actin filaments and possibly microtubules (Oleynikov and Singer 2003). $\beta$-Actin mRNA was also shown to bind elongation factor $1 \alpha$, which in turn can bind to F-actin. Although binding to eEF- $1 \alpha$ does not require the presence of the zipcode, eEF- $1 \alpha$ provides a means of anchoring the mRNA with the actin filaments and the translation machinery (Liu et al. 2002). Therefore, delivering the $\beta$-actin mRNA to its distal peripheral location and anchoring this mRNA at this site for translation may require different cis elements and trans-acting factors. In contrast, the same cis element of vimentin mRNA may place the mRNA in the perinuclear region and anchor it at this site to allow translation by interacting with the cellular translation machinery. It has been shown that the perinuclear localization signal of vimentin mRNA binds Hax-1, eEF1 $\alpha$, and RIP (Al-Maghrebi et al. 2002). Interestingly, both Hax-1 and eEF1 $\alpha$ are present in the endoplasmic reticulum (Sanders et al. 1996; Gallagher et al. 2000). Thus, in the case of vimentin mRNA, the interaction between the zipcode sequence and an ER protein may anchor the mRNA at the ER after exiting the nucleus. Further interaction between mRNA and the elongation factor may also promote translation.

In the studies reported here, we have examined the cytoplasmic localization of skeletal slow troponin C (sTnC) and slow troponin I (sTnI) mRNAs in muscle cells. sTnC is an important subunit of the muscle thin filament and is involved in the regulation of muscle contraction by $\mathrm{Ca}^{2+}$ (Potter and Gergely 1975). Two isoforms of TnC, the fast and the slow, are expressed in the skeletal muscle in a developmentally controlled manner. The $\mathrm{C}_{2} \mathrm{C}_{12}$ myoblasts derived from mouse skeletal muscle predominantly express the slow TnC isoform upon differentiation into myotubes (Parmacek and Leiden 1991). The TnI is another subunit of the troponin complex of thin filaments. Its main role is to control muscle contraction through its interaction with $\mathrm{TnC}$, troponin $\mathrm{T}$, and tropomyosin (Manhertz and Goody 1976). Several isoforms of TnI are found in skeletal muscles (Dhoot et al. 1978). The $\mathrm{C}_{2} \mathrm{C}_{12}$ muscle cells express both the slow (s) and fast (f) isoforms of TnI (Ojala et al. 1998).

Previous studies (Kislauskis et al. 1993) have shown that the $\alpha$-actin mRNA, which encodes a member of thin filaments of muscle cells, is localized in the perinuclear region. We have shown here that mRNAs encoding two additional members, the sTnC and sTnI, of the thin filament localized in the perinuclear region of muscle cells. This observation has raised the possibility that different muscle specific mRNAs can colocalize in muscle cells in order to permit the rapid assembly of translated proteins into myofilaments. We have also characterized the perinuclear localization signal of sTnC mRNA within a 40-nt-long region of its $3^{\prime}$ UTR. This localization signal was found to function only in the differentiated muscle cells. A polypeptide of $42 \mathrm{kDa}$ from differentiated myotubes, but not from the nondifferentiated proliferating myoblasts, binds to the sTnC mRNA localization signal. We propose that this $42-\mathrm{kDa}$ protein plays a role in localizing sTnC mRNA in perinuclear cytoplasm.

\section{RESULTS}

\section{Intracellular localization of $s \mathrm{TnC}$ and sTnI transcripts in muscle cells}

Differentiation of $\mathrm{C}_{2} \mathrm{C}_{12}$ myoblasts in culture, by mitogen withdrawal, leads to the coordinated activation of genes for contractile proteins and subsequent assembly of these proteins into myofilaments. The synthesis of these polypeptides within a specific region of the cytoplasm by colocalizing different mRNAs is likely to facilitate the assembly of myofilaments. To test the above postulate, we examined the distribution of $\alpha$-actin, sTnC, and sTnI mRNAs in muscle cells by in situ hybridization with fluorescent labeled molecular beacon probes (Tyagi and Kramer 1996; Sokol et al. 1998; Marras et al. 2002).

We first tested the specificity of these probes by using the proliferating nondifferentiated myoblasts for in situ hybridization. The results show that the muscle $\alpha$-actin, sTnC, and sTnI mRNAs were not detected in proliferating myoblasts (Fig. 1a-c). The low level of diffuse fluorescence seen here was due to autofluorescence. However, the nonmuscle isoform of actin, the $\beta$-actin mRNA, was easily detected in 

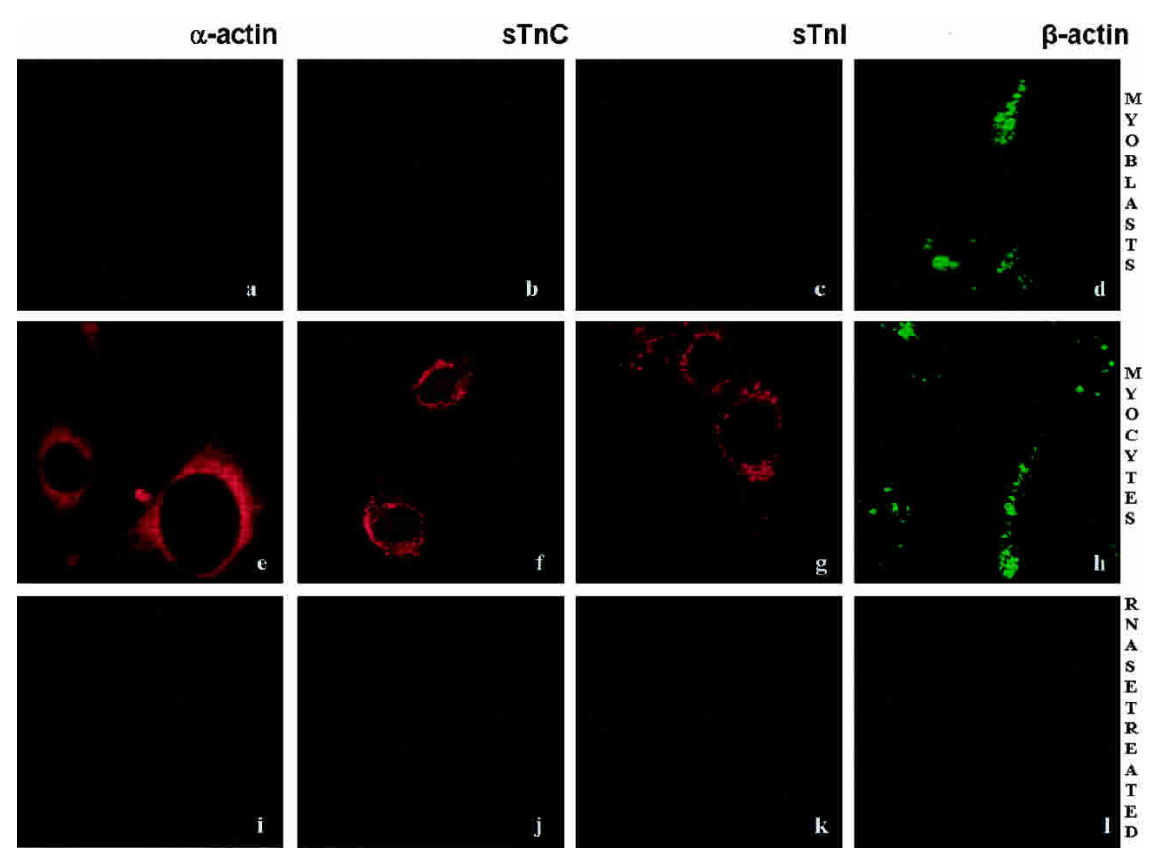

FIGURE 1. Intracellular distribution of mRNAs. Mouse $\mathrm{C}_{2} \mathrm{C}_{12}$ cells were cultured on glass coverslips either as proliferating myoblasts or allowed to differentiate in the low-mitogencontaining medium. In situ hybridization with molecular beacon probes was performed, and specimens were examined by CSLM as described in Materials and Methods. Approximately $30-40$ cells in 10 randomly chosen areas of the slide were viewed. The probes for detecting $\alpha$ and $\beta$-actin mRNAs were labeled with CY3 and FAM, respectively. The probes for detecting sTnC and sTnI mRNAs were both labeled with TET. $(a-d)$ In situ hybridization of myoblasts with $\alpha$-actin $(a), \operatorname{sTnC}(b), \operatorname{sinI}(c)$, and $\beta$-actin $(d)$ probes. Note the absence of strong signals for the muscle-specific mRNAs $(a-c)$ in myoblasts and the presence of strong signals for nonmuscle $\beta$-actin mRNA. $(e, h)$ In situ hybridization of differentiated myocytes that were maintained in the differentiation medium for $3 \mathrm{~d}$. The strong hybridization signals for $\alpha$-actin $(e), \operatorname{sinC}(f), \sin I(g)$, and $\beta$-actin $(h)$ can be seen. All three muscle-specific mRNAs show a concentration of signals around the nucleus, whereas the nonmuscle $\beta$-actin mRNA was concentrated near the leading edges in both myoblast $(d)$ and myocytes $(h)$. Fluorescent signal above the background was not detected when RNAse-treated specimens were hybridized to $\alpha$-actin, $\beta$-actin, TnC, and TnI probes ( $i-l$, respectively).

proliferating myoblasts, and as previously shown (Kislauskis et al. 1993), the $\beta$-actin mRNA was distributed predominantly in the peripheral region near the leading edge of myoblasts (Fig. 1d). The low level of diffuse signal seen here was equivalent to the level derived from the autofluorescence. To examine the mRNA localization in differentiated cells, we used $\mathrm{C}_{2} \mathrm{C}_{12}$ cells after $3 \mathrm{~d}$ of differentiation in the low mitogen containing medium. At this time the expression of muscle-specific mRNAs can be observed, although the majority of cells were present as mononucleated myocytes and did not show morphological differentiation into multinucleated myotubes (Silbertstein et al. 1986). We found that it was easier to monitor mRNA localization in the mononucleated cells and in the small myotubes with two to three nuclei. As an additional control, we examined whether the fluorescence signal was due to the hybridization of the probe to the RNA by using RNAse treated specimens. The results (Fig. 1,i-l) show that for all four probes, no signal was detected in RNAse treated cells.
The results of the in situ hybridization of mRNAs with molecular beacon probes in differentiated cells are shown in Figure 1e-h. For each experiment, specimens were examined in 10 randomly selected fields, and the fluorescently labeled cells were scored for perinuclear and peripheral or a diffuse distribution pattern of the signal. The relative levels of fluorescence in the different regions of the cell were analyzed by measuring pixel counts in six $1-\mathrm{mm}^{2}$ areas of the digital images. In these experiments nearly $80 \%-90 \%$ of the cells showed expression of muscle-specific mRNAs. A typical $\alpha$-actin mRNA distribution pattern in two myocytes is shown (Fig. 1e). In both cells, the $\alpha$-actin mRNA was highly concentrated near the nucleus. Diffuse fluorescent signals outside of the perinuclear cytoplasm was also detectable in these cells. However, after subtracting the background fluorescence of myoblasts (Fig. 1a), it was determined that $>75 \%$ of $\alpha$-actin mRNA was localized in the perinuclear region. This pattern of $\alpha$-actin mRNA distribution was observed in almost $80 \%$ of the fluorescently labeled cells. The distribution pattern of $\alpha$-actin mRNA was in sharp contrast to that of the $\beta$-actin mRNA in myoblasts where no perinuclear $\beta$-actin mRNA localization was observed. These results also suggest that the observed perinuclear distribution of $\alpha$-actin mRNA was not due to the greater thickness of the cell, and hence presence of more cytoplasmic materials around the nucleus. Furthermore, the $\alpha$-actin mRNA distribution pattern shown here is similar to the previously reported distribution pattern of $\alpha$-actin mRNA in chicken muscle cells in culture (Kislauskis et al. 1993). Our analyses also show that after $3 \mathrm{~d}$ in differentiation medium, the $\mathrm{C}_{2} \mathrm{C}_{12}$ cells still expressed significant levels of the nonmuscle $\beta$-actin mRNA. Nearly $100 \%$ of the cells showed $\beta$-actin expression, and $>80 \%$ of the cells in all randomly chosen fields showed the peripheral localization of $\beta$-actin mRNA in myocytes (Fig. 1h). In most myocytes, a small amount of the $\beta$-actin mRNA was present in the perinuclear region, but there was no detectable signal in between the perinuclear and distal peripheral regions. The $\beta$-actin mRNA in both myoblasts and myocytes were present as large granular structures. The perinuclear $\alpha$-actin mRNA was also present as granules, albeit less distinct than that of the $\beta$-actin mRNA. No detectable granular structure of $\alpha$-actin mRNA was present in the peripheral region of 
myocytes. The results of these studies confirm a previous observation that the $\alpha$ - and $\beta$-actin mRNAs have distinct cellular localization patterns (Kislauskis et al. 1993) and serve as good controls for examining sTnC and sTnI mRNA localization.

The in situ hybridization of molecular beacon probes for sTnC and sTnI mRNAs, using differentiated cells, showed very similar patterns of perinuclear localization. Both mRNAs appeared to be highly concentrated around the nucleus in dense granular structures (Fig. 1f,g). Also, some regions around the nucleus had higher concentrations of both sTnC and sTnI mRNAs than other perinuclear locations. It is unknown at this time whether the higher density of these mRNAs represents the exit points from the nucleus or specific anchoring points for these mRNAs in the perinuclear cytoplasm. The distribution pattern of these two thin filament protein coding mRNAs was similar to that of the $\alpha$-actin mRNA, which also encodes a thin filament protein but was distinct from that of the $\beta$-actin mRNA, which encodes the cytoskeletal actin present in almost all higher eukaryotes. These distribution patterns were highly reproducible in more than six separate in situ hybridization experiments. Furthermore, $>80 \%$ of the cells showed similar distribution patterns. Also, $>80 \%$ of the fluorescence signals for sTnC and sTnI mRNA was present in the perinuclear region. These observations suggest that mRNAs that encode different thin filament polypeptide partners may be localized and translated in the same vicinity, and cotranslationally assembled into the thin filament structure.

\section{The sTnC mRNA localization signal}

The ability to localize mRNA to a specific cytoplasmic domain may reside within its cis-acting element. To characterize the sTnC mRNA perinuclear localization signal we tested the ability of different regions of the sTnC mRNA to confer perinuclear localization on the reporter $\beta$-Gal mRNA. Different regions of the sTnC mRNA were fused at the 3' UTR of the $\beta$-Gal gene under the control of a CMV promoter. Following the transfection of differentiating $\mathrm{C}_{2} \mathrm{C}_{12}$ cells with the chimeric $\beta$-Gal construct, the cytoplasmic distribution of the $\beta$-Gal mRNA was examined by in situ hybridization. Approximately 50 transfected cells expressing $\beta$-Gal mRNA were scored for the perinuclear localization of the reporter mRNA. The average results from six independent transfection experiments are shown (Fig. 2).

More than $85 \%$ of transfected cells showed the perinuclear localization of $\beta$-Gal mRNA when the 3' UTR of the sTnC mRNA was present in the reporter construct (A). In contrast, the presence of the $5^{\prime}$ UTR (B), or the entire coding region and the $5^{\prime}$ UTR (C) did not confer perinuclear localization on the reporter mRNA. The distribution of $\beta-G a l$ mRNA in cells transfected with either the $B$ or the $\mathrm{C}$ construct was diffuse and similar to those observed in

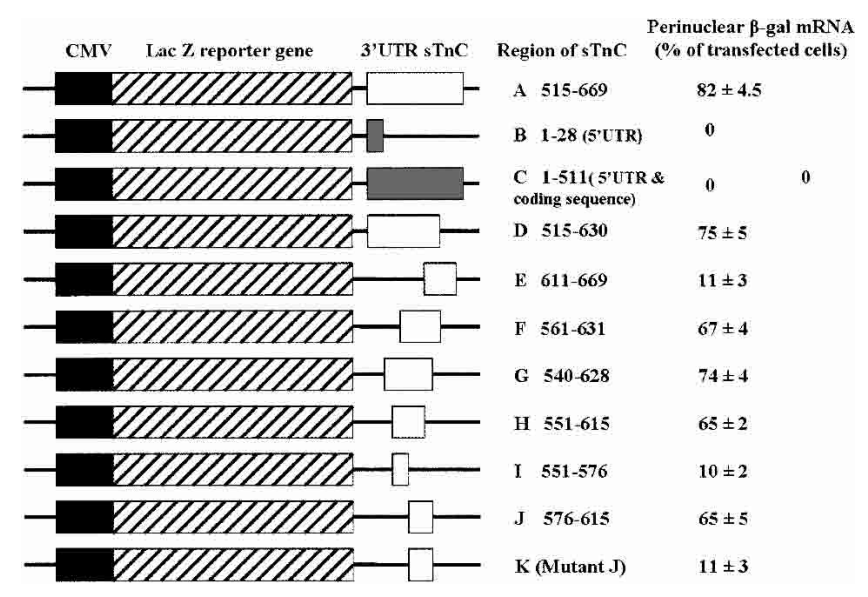

FIGURE 2. Distribution of $\beta$-Gal mRNA in transiently transfected $\mathrm{C}_{2} \mathrm{C}_{12}$ myocytes with $\beta$-gal-sTnC chimeras. These are schematic representations (not drawn to scale) of the different constructs used for $\beta$-Gal distribution studies. The CMV promoter (solid black box), and the Lac $\mathrm{Z}$ reporter gene (hatched box), the different segments of sTnC $3^{\prime}$ UTR sequences (open box), the $5^{\prime}$ untranslated region, and the coding region (gray box) are shown. Various regions of the sTnC mRNA were fused to the Lac $\mathrm{Z}$ reporter gene. Cells were transfected with each construct, and the cytoplasmic distribution of the $\beta-G a l$ mRNA was analyzed by in situ hybridization. Approximately 50 transfected cells were examined, and the percentage of cells showing perinuclear localization was scored. The averages were calculated from six independent experiments.

cells transfected with the parent pCMV SPORT- $\beta$-Gal vector. The representative perinuclear and diffuse distribution of the $\beta$-Gal mRNA are shown in Figure 4 (below) and will be discussed in detail later.

Further studies were performed in order to precisely define the localization signal. $\beta$-Gal fusion constructs, comprising different regions of the $3^{\prime}$ UTR of sTnC mRNA, were made and tested in differentiating $\mathrm{C}_{2} \mathrm{C}_{12}$ cells. Results demonstrate that significant perinuclear localization activity was present within nucleotides $576-615$ of the sTnC mRNA (Fig. 2, construct J). Nearly $65 \%$ of cells expressing $\beta$-Gal mRNA bearing this region of the sTnC mRNA showed the perinuclear distribution of the reporter mRNA. Analysis of the predicted secondary structure of this region suggests the presence of alternating stem and loop structures (Fig. 3A, region I). Although the presence of this 40-nt-long region alone in the chimeric construct conferred perinuclear localization, the presence of additional stem and loop containing regions (Fig. 3A, regions II and III) showed a small additive effect (constructs A and G). The presence of the 40-nt-long region I was essential for the perinuclear localization of the reporter mRNA. Constructs E and I, lacking region I of the sTnC mRNA, had no significant perinuclear localization activity.

To assess the importance of the potential secondary structure of the localization signal, we tested a construct with mutations within the double-stranded regions of the zipcode. The base pairing in the predicted double-stranded regions of the zipcode was disrupted by replacing the 
A

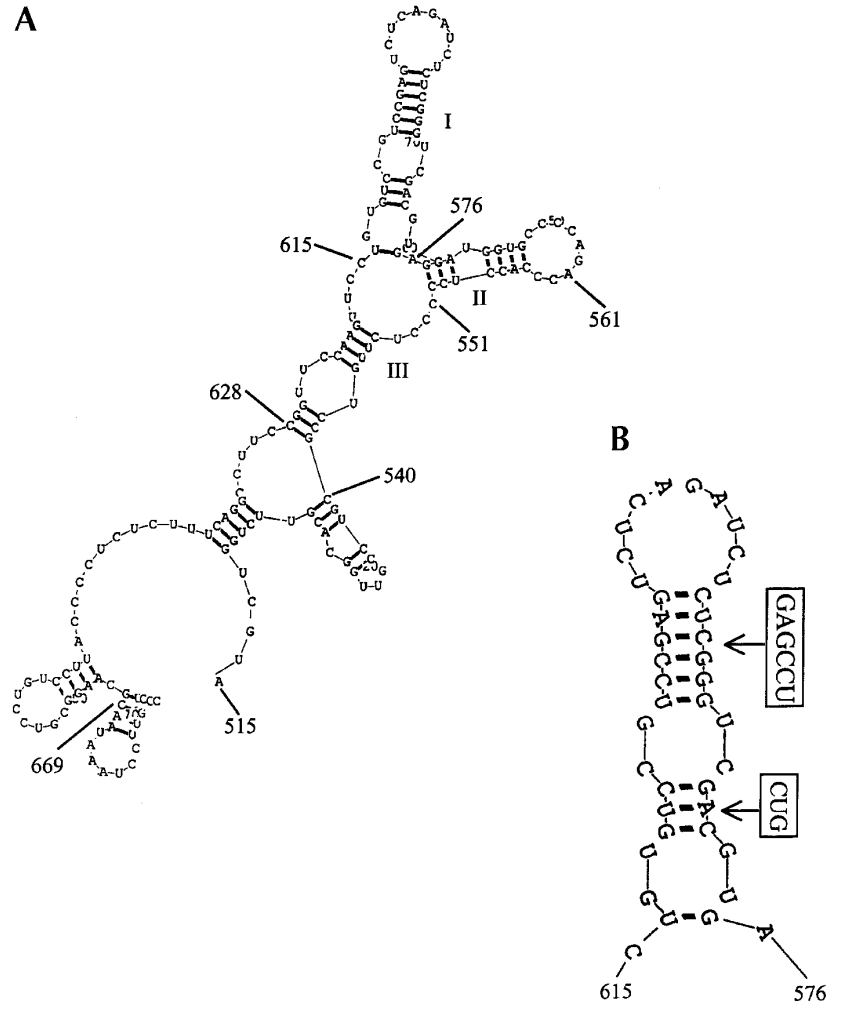

FIGURE 3. The folding of the $3^{\prime}$ UTR of sTnC mRNA. The predicted secondary structure of $(A)$ the entire $3^{\prime}$ UTR of sTnC mRNA excluding the last $18 \mathrm{nt}$ containing the poly(A) addition signal, and $(B)$ the 40-nt-long localization signal are shown. The structures were predicted using the RNA structure version 2.5 computer algorithm. The boxed nucleotides $(B)$ indicate the base substitutions used in construct K (Fig. 2). The different stem and loop arrangements within nucleotides 540-628 have been designated as regions I, II, and III. The numbering refers to the nucleotide numbers of the sTnC mRNA beginning at its $5^{\prime}$ end (accession number AA656586).

complementary bases (Fig. 3B). The transfection of differentiating $\mathrm{C}_{2} \mathrm{C}_{12}$ cells, with the reporter $\beta$-Gal construct containing the mutated zipcode, showed significantly reduced localization activity (Fig. 2, construct K). These results suggest that the secondary structure of the localization signal is essential to its function.

To determine the specificity of the $\beta$-Gal probe, we first examined mock transfected and RNase treated cells for hybridization with the probe. All specimens were first examined under a phase contrast (Nomarski) field, and healthy specimens were examined for fluorescence emitted by the Cy3 fluorophore upon hybridization to the $\beta$-Gal mRNA. Cells in 10 randomly selected fields were observed and Figure 4 illustrates the representative distribution pattern of $\beta$-Gal mRNA in transfected cells. The results show that mock transfected or RNase treated cells transfected with construct A did not show signals above the background level. On the other hand, cells transfected with all four $\beta$-Gal expression vectors (A, J, K, and $\beta$-Gal) showed a significant level of the fluorescence signal. The $\beta-G a l$ mRNA localization in construct A and J transfected cells showed the perinuclear distribution of the reporter mRNA. Most of the $\beta$-Gal mRNA signal was found within $2 \mu \mathrm{m}$ of the nuclear membrane (Fig. 4d). On the other hand, the $\beta$-Gal mRNA distribution was diffuse in cells transfected with the construct $\mathrm{K}$ carrying several substitution mutations to abolish potential base pairing in the zipcode sequence. The $\beta$-Gal mRNA distribution in these cells was similar to that observed in cells transfected with the parent $\beta-G a l$ vector (pCMV-SPORT $\beta$-Gal). In both cases the line scan (Fig. $4 \mathrm{~d}$ ) shows the diffuse distribution of the red signal. The transfection efficiency of differentiating $\mathrm{C}_{2} \mathrm{C}_{12}$ cells is usually low (20\%-30\%). Therefore, we can only see one or two transfected cells in the field of view. The remaining nontransfected cells did not show any fluorescence signal above the background, suggesting that the signal seen in transfected cells was due to the hybridization of the probe to the reporter $\beta$-Gal mRNA.

We also examined whether the sTnC mRNA localization signal is specific to the differentiated cells by testing its localization activity in proliferating myoblasts and HeLa cells. Our results reveal that the localization signal of sTnC mRNA was unable to direct $\beta$-Gal localization to the perinuclear region in proliferating myoblast and HeLa cells (Fig. 5). The cytoplasmic distribution pattern of the $\beta-G a l$ mRNA in these cells was similar to what was observed when differentiated myotubes (Fig. 4), proliferating myoblasts, and HeLa (Fig. 5) cells were transfected with the pCMVSPORT- $\beta-G a l$ construct lacking the $3^{\prime}$ UTR of sTnC mRNA. Representative figures of myoblasts and HeLa cells (Fig. $5 \mathrm{a}-\mathrm{c}$ ) and the line scan of the fluorescence signal (Fig. $5 \mathrm{~d})$ show that the $\beta$-Gal mRNA was distributed almost uniformly throughout the cytoplasm. These findings imply that the perinuclear localization signal of sTnC mRNA functions only in the differentiated muscle cells. These results are different from other previously studied localization signals that did not show cell specificity (Gu et al. 2002).

\section{及-Gal polypeptide and mRNA levels in transfected cells}

The 3' UTR of mRNA may contain cis-elements that control the stability and translation of mRNA (Jackson 1993; Decker and Parler 1995). In the studies reported above, we fused different regions of the 3' UTR of sTnC mRNA to the $\beta$-Gal gene. Thus, the expressed mRNAs from different reporter genes may have differential stability and efficiency of translation, which in turn could produce various levels of $\beta$-Gal and influence its cytoplasmic localization. Moreover, in the absence of proper cytoplasmic localization, the mRNA may be rapidly degraded. We examined whether or not different reporter constructs were equally expressed in transfected cells. For these studies the level of expression of the $\beta$-Gal polypeptide and its mRNA were measured. Also, to correct for differences in transfection efficiency between experiments, cells were cotransfected with a GFP expression 


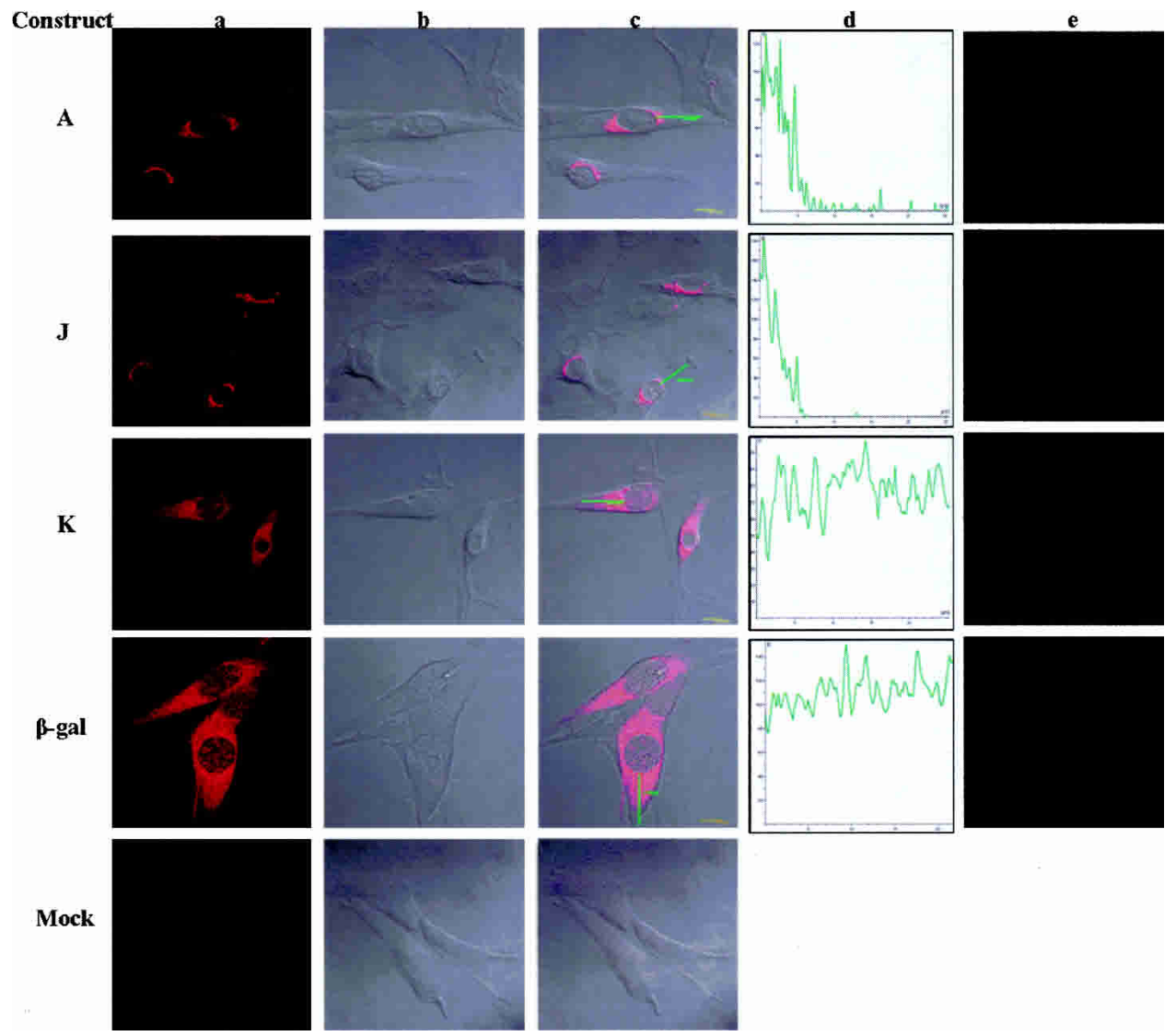

FIGURE 4. Regulation of cytoplasmic distribution of $\beta$-Gal mRNA by the $3^{\prime}$ UTR of sTnC mRNA in differentiated muscle cells. Differentiating $\mathrm{C}_{2} \mathrm{C}_{12}$ cells were transfected with different $\beta$-Gal constructs as described in Materials and Methods. Twenty-four hours after transfection, the cells were fixed, and the cytoplasmic distribution of the $\beta$-Gal mRNA was examined by in situ hybridization. Cells transfected with constructs A and J (Fig. 2) show the perinuclear distribution of $\beta$-Gal mRNA. In contrast, cells transfected with the mutant zipcode containing construct K (Fig. 2 ) show a diffuse distribution of $\beta$-Gal mRNA. The parent pCMV-SPORT- $\beta-G a l$ ( $\beta$-Gal) transfected cells also show diffuse distribution of the $\beta$-Gal mRNA. Fluorescent signal is not visible in mock-transfected and RNAse-treated cells. The panels are as follows: $(a)$ fluorescent signal of the Cy3-labeled hybridized probe; $(b)$ phase contrast pictures (Nomarski) of the cells shown in panel $a$; $(c)$ panels $a$ and $b$ are merged; $(d)$ line scans of fluorescent cells in panel $a$ using the Leica software; and (e) hybridization of RNAse-treated cells with the $\beta$-Gal molecular beacon probe.

vector, and the level of GFP expression was used to normalize our results. The $\beta-G a l$ and GFP polypeptide levels were measured by Western blotting using appropriate antibodies. The results show that the level of $\beta$-Gal in cells transfected with the different constructs was similar. A maximum of $\sim 30 \%$ difference in $\beta$-Gal level was observed between constructs that exhibited localization (Fig. 6, lanes 2-4) and those that did not (Fig. 6, lanes 5,6). These results suggest that the perinuclear localization signal had no significant effect on the $\beta$-Gal polypeptide level in cells. Similarly, measurements of $\beta$-Gal and GFP mRNA levels, by using mRNA specific primers during RT-PCR as described in Materials and Methods, show that the $\beta$-Gal mRNA levels were approximately similar in cells transfected with different regions of the sTnC mRNA 3' UTR bearing constructs. Hence, the results of our analyses suggest that the failure of the reporter mRNA to localize in the perinuclear region of muscle cells had no significant effect on its translation and stability.

\section{Localization signal binding polypeptides}

RNA binding proteins play important roles in the posttranscriptional regulation of gene expression. Some of these proteins may facilitate RNA localization by binding to targeting signals for the transport of RNA molecules to distinct intracellular domains (Siomi and Dreyfuss 1997). We have, therefore, investigated the presence of sTnC mRNA localization signal-binding proteins in muscle cells. For these studies $\left[{ }^{32} \mathrm{P}\right]$-labeled 40 -nt-long localization signal RNA was synthesized in vitro and mixed with either myoblast or myotube cell extracts. The RNA-protein complexes were cross-linked by UV light as described in Materials and Methods. The polypeptides that were covalently bound to the $\left[{ }^{32} \mathrm{P}\right]$-labeled RNA, following UV treatment, were analyzed by SDS-PAGE after digesting the non-cross-linked RNA with RNases. The results show that three polypeptides of $\sim 68,60$, and $42 \mathrm{kDa}$ from myotubes bind to the localization signal (Fig. 7, lane e). However, only two of these 


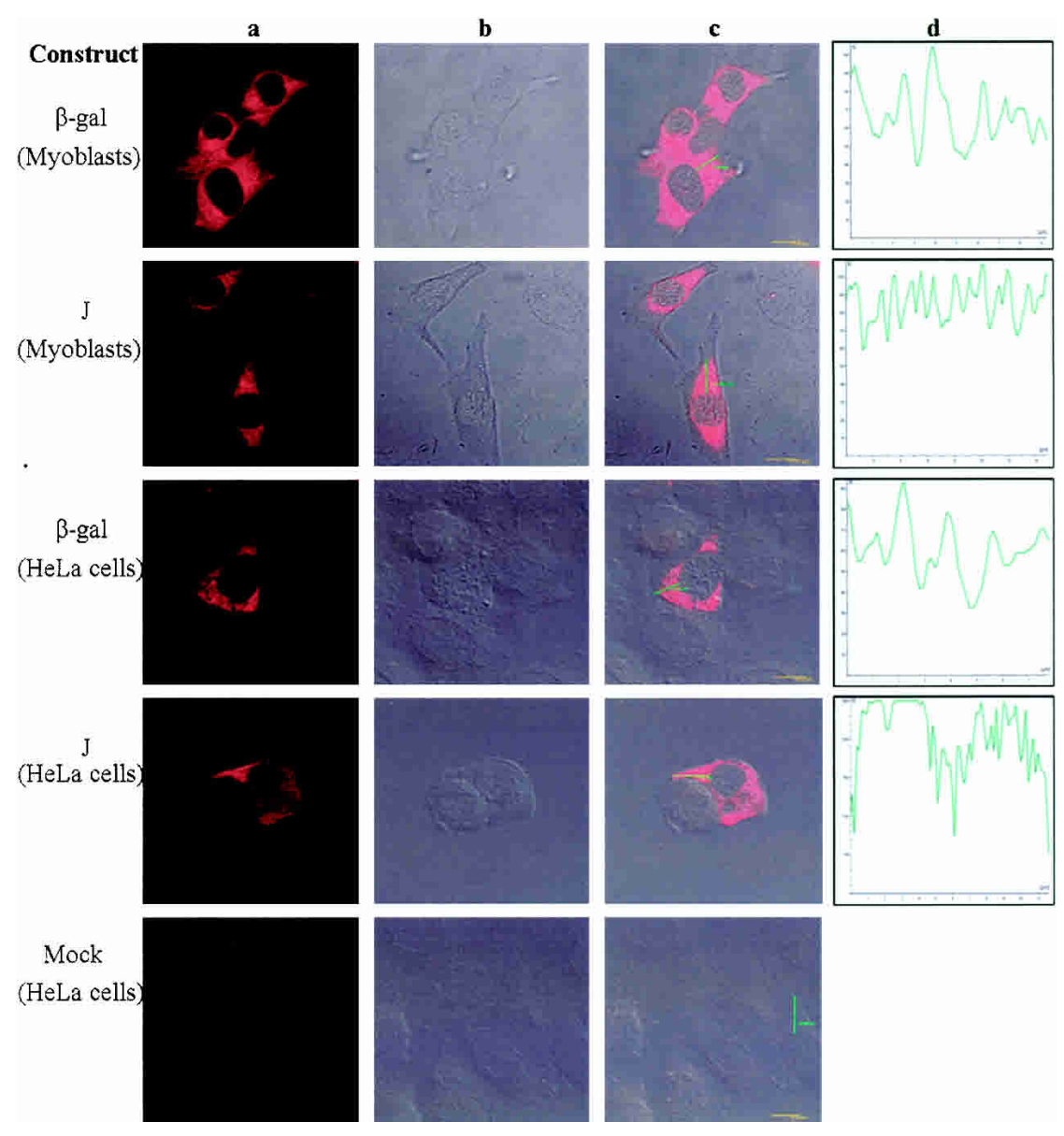

FIGURE 5. Cell specificity of sTnC mRNA localization signal. Proliferating $\mathrm{C}_{2} \mathrm{C}_{12}$ myoblasts and HeLa cells were transfected with pCMV-SPORT- $\beta$-Gal or construct J containing the sTnC mRNAs 40-nt-long localization signal. Twenty-four hours after transfection, the cytoplasmic distribution of $\beta$-Gal mRNA was examined as described in Materials and Methods. (a) The diffuse distribution of $\beta$-Gal mRNA in cells transfected with pCMV-SPORT- $\beta-G a l$ ( $\beta$-Gal) or construct J. The panels are as follows: $(a)$ fluorescent signal of hybridized probe; $(b)$ Nomarski picture of the cell in panel $a$; $(c)$ panels $a$ and $b$ are merged; and $(d)$ line scan of fluorescent cells in panel $a$.

three polypeptides from myoblasts were able to bind the localization signal (Fig. 7, lane d). The $68-$ and $60-\mathrm{kDa}$ polypeptides were present in both myotube and myoblast extracts. The $42-\mathrm{kDa}$ localization signal-binding polypeptide was found only in the myotubes. Also a significantly higher level of the $68-\mathrm{kDa}$ polypeptide was found in the myotubes. This was neither due to a difference in the protein concentration nor in the quality of the preparations between the two extracts. The level of binding of the $60-\mathrm{kDa}$ polypeptide to the RNA was almost equivalent between the two extracts. Before being used for the RNA binding experiments, the protein content of both extracts was measured and analyzed by SDS-polyacrylamide gel electrophoresis. As judged by the Coomassie blue stained gels, both extracts were similar in their qualities (Fig. 7B). To investigate which of these polypeptides showed specificity for the localization signal and were not indistinct RNA binding polypeptides, we analyzed the binding activity of these poly- peptides for the mutant localization signal that did not show localization activity in the $\beta$-Gal mRNA localization assays (Fig. 4). The results of UV-induced RNA-protein cross-linking studies show that the 68 - and $60-\mathrm{kDa}$ polypeptides of both myoblasts and myotubes could bind to the mutant localization signal (Fig. 7, lanes b,c). The 42-kDa polypeptide of myotubes did not bind to the mutant RNA (Fig. 7, lane c). Furthermore, the observed difference in the binding of the $68-\mathrm{kDa}$ polypeptide to the wild-type RNA between myotubes and myoblasts was not evident when the mutant RNA was used in UV-induced cross-linking experiments (Fig. 7, cf. lanes $\mathrm{b}$ and $\mathrm{d}$ ). Therefore, $68-\mathrm{kDa}$ and $60-\mathrm{kDa}$ polypeptides may represent nonspecific RNA binding proteins. As additional controls, we tested the ability of two RNAs, corresponding to regions of the 3' UTR of sTnC mRNA, that did not have any significant zipcode activity to interact with the $42-\mathrm{kDa}$ polypeptide of myotubes. We chose RNAs corresponding to nucleotides 551-576 (Fig. 2, construct I) and 611-669 (Fig. 2, construct E) of the sTnC mRNA. The results of UV-induced cross-linking studies show that the RNA E binds to the 68and $60-\mathrm{kDa}$ polypeptides, but the shorter RNA I did not show significant binding to any protein. Neither of these two RNAs showed binding ability to the $42-\mathrm{kDA}$ polypeptide. Collectively, these results suggest that the $42-\mathrm{kDa}$ myotube-specific polypeptide may be the true sTnC mRNA zipcode-binding polypeptide. The results of the RNA-protein binding studies also explain the observed cell specificity of the localization signal in the $\beta$-Gal reporter assays (Fig. 5). In addition to the $42-\mathrm{kDa}$ polypeptide, the increased level of the $68-\mathrm{kDa}$ polypeptide in myotubes may also be important for the perinuclear localization of the sTnC mRNA in differentiated muscle cells. It is possible that an additional zipcode-binding polypeptide of a similar size is present only in myotubes. These binding patterns were observed reproducibly in four experiments using different extracts.

\section{DISCUSSION}

\section{Perinuclear localization of thin filament mRNAs}

The activation of the myogeneic program is a complex process that leads to the coordinate expression of several con- 


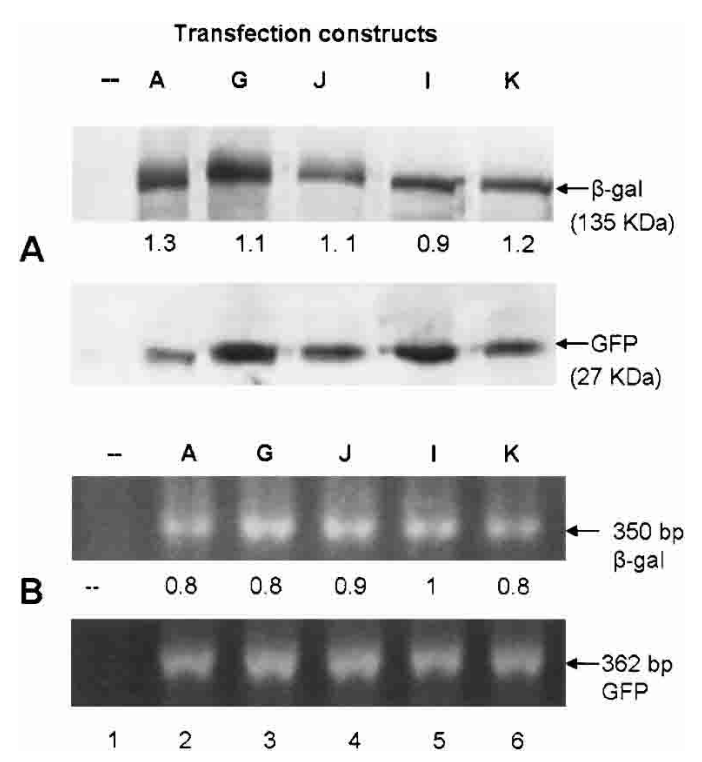

FIGURE 6. Levels of $\beta$-Gal polypeptide and mRNA in cells transfected with different $\beta$-gal-sTnC chimeric constructs. Differentiating $\mathrm{C}_{2} \mathrm{C}_{12}$ cells were cotransfected with a $\beta$-gal-sTnC chimeric construct and a GFP expression vector. Twenty-four hours after transfection, cells were either lysed directly in the SDS gel-loading buffer or harvested for RNA isolation as described in Materials and Methods. Levels of $\beta$-Gal and GFP polypeptides were analyzed by Western blotting $(A)$. Approximately equal amounts of protein from each sample were subjected to SDS-PAGE and transferred to a nitrocellulose membrane. The membrane was probed with $\beta$-Gal and GFP antibodies separately as described in Materials and Methods. Levels of $\beta$-gal and GFP mRNAs were determined by RT-PCR as described in Materials and Methods (B). Equal amounts of RNA were used for RT-PCR using $\beta$-gal and GFP mRNA specific primers. The PCR product was analyzed by $2 \%$ agarose gel electrophoresis. The Western blot and the gel pictures were scanned using a Canoscan $500 \mathrm{~F}$ scanner. The images were saved as TIFF files, and levels of protein and mRNAs were quantified by using the image-analysis software, Scion Image for Windows. Polypeptide and mRNA levels in untransfected cells (lane 1) and in cells transfected individually with construct A, G, J, I, and K (lanes $2-6$, respectively) are shown by an arbitrary unit. The $\beta$-Gal polypeptide and mRNA levels were normalized for the difference in transfection efficiency between experiments by using GFP mRNA and protein levels.

tractile protein-genes and to the subsequent assembly of these proteins into myofilaments (Muntoni et al. 2002). The results of our studies suggest that these coordinately expressed mRNAs probably have the same cytoplasmic destination.

It was previously shown that the muscle specific $\alpha$-cardiac actin mRNA localizes in the perinuclear cytoplasm of muscle cells (Lawrence and Singer 1986; Hill and Gunning 1993; Kislauskis et al. 1993). In this report we have shown that two additional muscle-specific mRNAs, sTnC and sTnI, are also localized in the perinuclear cytoplasm. Therefore, the localization of several muscle-specific mRNAs in the perinuclear region to produce the corresponding polypeptides in the same vicinity may be required for their rapid assembly into the myofilament.

Several mRNAs including c-Fos, c-Myc, and vimentin were previously shown to localize in the perinuclear region (Cripe et al. 1993; Veyrune et al. 1996; Dalgleish et al. 2001). Since this region contains the endoplasmic reticulum and translationally active ribosomes, it may be a common destination for many mRNAs. This may be particularly true for mRNAs that encode transcriptional regulators. The c-Fos and c-Myc proteins are rapidly expressed and accumulate in the nucleus in response to growth factors (Bishop 1987). Therefore, localizing these mRNAs at the site of active protein synthesis near the nucleus may guarantee the rapid translation and efficient entry of the polypeptides into the nucleus. In contrast to c-Fos and c-Myc, the vimentin and sTnC and sTnI are produced in large quantities and are a part of complex multicomponent cellular structures. Efficient translation of these mRNAs may be required to produce large quantities of these polypeptides, which may be facilitated by the perinuclear localization of the mRNAs. The presence of three different mRNAs encoding the $\alpha$-actin, sTnC, and sTnI subunits of the thin filament in the perinuclear region of myocytes gives credence to the idea of the cotranslational assembly of the thin filament structure. Similar processes may also be involved in the assembly of the muscle thick filament as the myosin-heavy chain mRNA also localizes in the perinuclear region (Wiseman et al. 1997). It is not known whether other thin and thick filament mRNAs, like troponin $\mathrm{T}$, tropomysin, and myosin

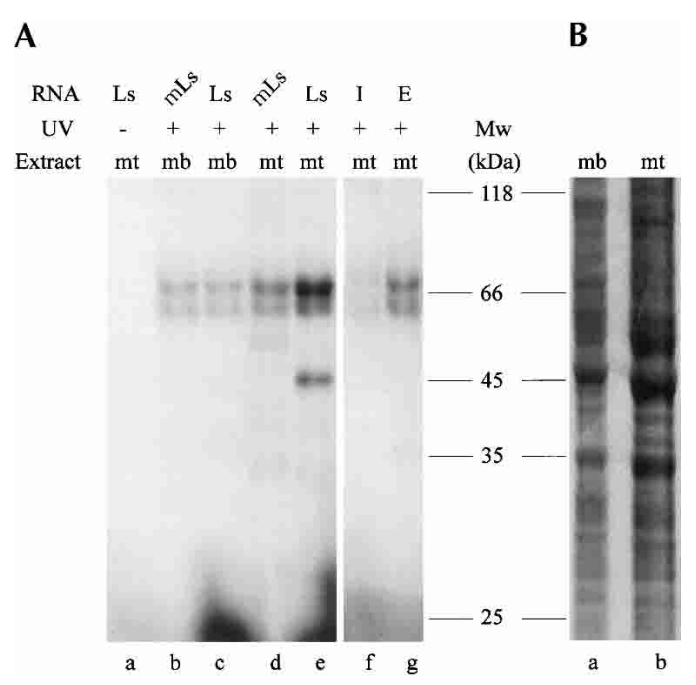

FIGURE 7. Proteins interacting with the localization signal of sTnC. Radiolabeled 40-nt-long localization signal RNA (LS) and the mutated LS RNA (mLS), and RNA corresponding to nucleotides 511-576 (I) and 611-669 (E) of the sTnC mRNA were synthesized in vitro as described in Materials and Methods. Approximately $50 \mathrm{pg}$ of $\left[{ }^{32} \mathrm{P}\right]-$ labeled RNA $(100,000 \mathrm{cpm})$ were mixed with $75 \mu \mathrm{g}$ of the total cellular proteins from either myoblasts $(\mathrm{mb})$ or myotubes $(\mathrm{mt})$. The sample was exposed to UV light for RNA-protein cross-linking as described in Materials and Methods. After digesting the RNA with RNase A and $\mathrm{T}_{1}$, the cross-linked samples were analyzed using 12\% SDS-PAGE and autoradiography $(A) .(B)$ The total cellular extracts of both myoblasts $(\mathrm{mb})$ and myotubes $(\mathrm{mt})$, which were analyzed by SDS-PAGE and stained with Coomassie Brilliant Blue. 
light chains also localize in the perinuclear cytoplasm. However, for the efficient and correct assembly of polypeptide partners into the thin filaments or thick filaments, it may not be necessary to synthesize all of them in the perinuclear region. Once some of the thin filament polypeptides are synthesized and assembled in the perinuclear region, other polypeptide partners could be attracted from a distal location toward the partially assembled complex to complete the thin filament assembly.

The distribution pattern of all four mRNAs examined in our studies appeared granular and nonhomogeneous. The $\alpha$-actin mRNA distribution was less granular than the sTnC, sTnI, and $\beta$-actin mRNAs. The size of the granules within a single cell was also different, and there was no obvious relationship between the granule size and its distance from the nuclei. It is not clear whether the mRNA exited the nucleus as a larger granule and then the size of the granule decreased as more cytoplasmic diffusion occurred or vice versa. The observed granular distribution pattern reported here is similar to those previously reported for a variety of different mRNAs (Bassell et al. 1998; Bermano et al. 2001; Dalgleish et al. 2001). These granules likely represent large RNA-protein complexes, including the translating ribosomes. Although we did not examine whether the mRNAs within the granules were translationally active, results of previous studies show that very little nontranslated $\alpha$-actin, sTnC, and sTnI mRNAs are present in differentiating muscle cells (Hastings and Emerson 1982). Hence, the mRNAs within the granules were most likely associated with polyribosomes and engaged in protein synthesis. Furthermore, approximately a 10 -fold difference in size between the smallest and the largest granules indicates that the largest granules contain many copies of the mRNA.

\section{Perinuclear localization signals}

Cellular mRNAs can be localized by a variety of mechanisms (Bashirullah et al. 1998; Lipshitz and Smibert 2000). However, one common feature is the presence of cis-acting localization signals. With few exceptions (Chartrand et al. 1999; Gonzalez et al. 1999; Saunders and Cohen 1999; Thio et al. 2000), the cis-acting localization signal or the zipcode for mRNA localization is present within the $3^{\prime}$ UTR. In our studies, we have shown that the sTnC mRNA localization signal is also present within a 40-nt-long region of its $3^{\prime}$ UTR. Although we have shown that this localization signal can confer perinuclear localization on the reporter $\beta$-Gal in muscle cells, we do not know whether the removal of this sequence from the sTnC mRNA itself abolishes its perinuclear localization. Earlier studies using $\beta$-actin mRNA showed that the first $54 \mathrm{nt}$ of the $\beta$-actin mRNA 3' UTR can direct the localization of a reporter RNA to the leading lamellae in fibroblasts, but its deletion does not abolish localization. Another 43-nt-long cis-acting element must also be deleted to completely abolish localization (Kislauskis et al. 1994). Generally, the localization signals are highly complex and consist of redundant localization elements. Our studies also suggest the presence of other elements that stimulate the localization activity of the 40-nt-long zipcode.

Besides the sTnC and sTnI mRNAs, the cytoplasmic localization of three other muscle-specific mRNAs has been studied-AchR, MHC, and $\alpha$-actin mRNAs. However, none of these mRNA localization signals have been fully characterized (Goldman and Staple 1989; Brenner et al. 1990; Kislauskis et al. 1993). The $\alpha$-actin, sTnC, and $s \operatorname{TnI}$ mRNAs encode different thin filament polypeptides and are all located in the perinuclear region, but there is no homology of the 40-nt-long sTnC mRNA localization signal to the $\alpha$-actin or sTnI $3^{\prime}$ UTR. Whether a structural similarity exists between the localization signal of these three mRNAs is not known. The perinuclear localization signals for chicken $\alpha$ cardiac actin (Kislauskis et al. 1993), mouse c-Fos (Dalgleish et al. 2001), human vimentin (Bermano et al. 2001), and mouse c-Myc (Veyrune et al. 1996) mRNAs have been shown to be present within a 151-, 145-, 101-, and 87-nt-long region of their $3^{\prime}$ UTRs, respectively. The sTnC mRNA appears to have the shortest perinuclear localization signal. One characteristic of the zipcodes mentioned above is the potential for the presence of extensive stem and loop structures. We have shown here that the presence of the two potential double-stranded stems in the sTnC mRNA zipcode is important for its localization activity. Disruption of the double-stranded region by introducing mutations in this region abolished its activity. It is interesting to note that the zipcodes of mouse sTnC, chicken $\alpha$-cardiac, and human vimentin mRNAs may fold into similar secondary structures representing a Y-fork (Fig. 8). Among these zipcodes, however, this secondary structure has been experimentally verified for only the vimentin mRNA (Zehner et al. 1997).

The exact role of the nucleotide sequence in the localization signal is not clear. Studies using bicoid RNA showed that compensatory mutations that restored the doublestranded helix also restored the localization signal (Macdonald and Kerr 1998). A similar study with the sTnC mRNA localization signal has not been performed yet. The function of the localization signal probably depends on the higher order folding of the RNA, which may depend on the length of the stem regions and the distance between the stem and loop regions. Further studies to examine the effect of the spatial position of the stem and loops in the localization signal may provide a better understanding of the localization machinery.

In these studies, we have shown that the sTnC mRNA localization signal is cell specific. The 40-nt-long localization signal sequence was unable to direct $\beta$-Gal mRNA to the perinuclear region in proliferating myoblasts and HeLa cells. This observation is unique because previous studies using the actin isoforms showed that the localization signals 
A

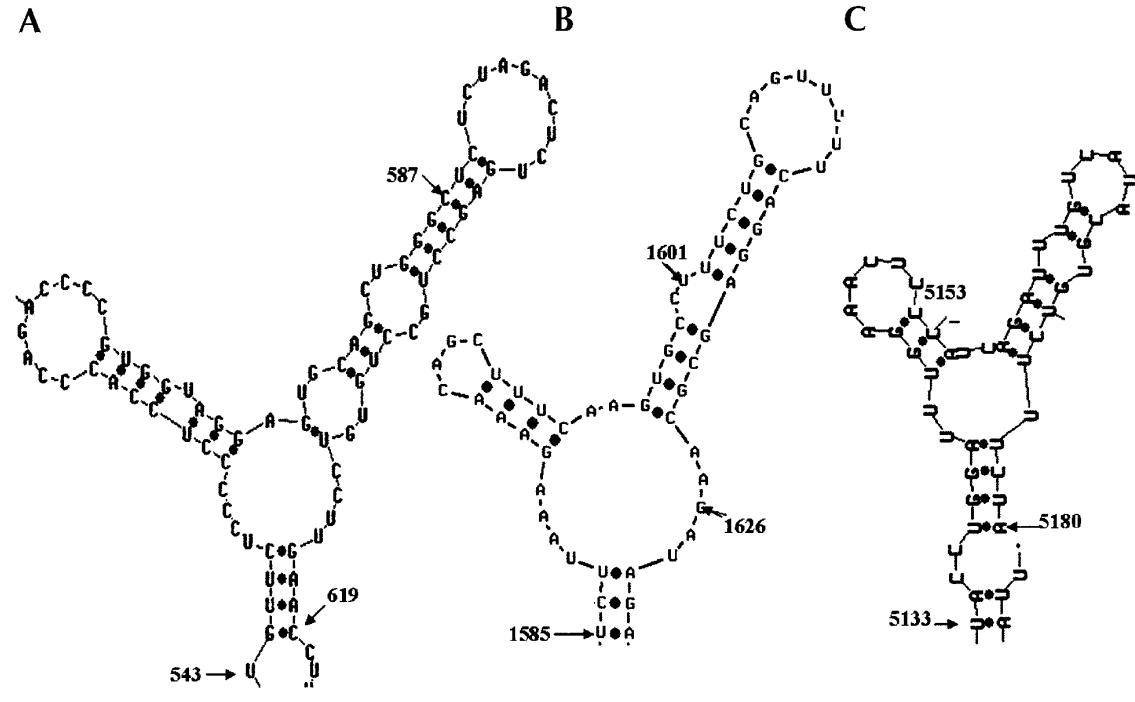

FIGURE 8. Predicted secondary structures of different perinuclear localization signals. The secondary structures of the perinuclear localization signals of mouse sTnC and human vimentin mRNAs were analyzed by the RNA structure version 2.5 algorithm. Numbering of the nucleotides begins at the $5^{\prime}$ end of mRNA. Here are the $(A)$ mouse slow/cardiac troponin $C$ mRNA zipcode region (nucleotides 543-623, accession number AA656586); (B) human vimentin mRNA zipcode region (nucleotides 1586-1640, accession number BC000163); and (C) chicken $\alpha$-cardiac actin mRNA zipcode region (nucleotides 5133-5180, accession number X02212).

also function in cells that do not normally express these mRNAs ( $\mathrm{Gu}$ et al. 2002). In the related literature we have found another example of cell specificity in the localization of mRNA. The $\mathrm{B}$ isoform of creatine kinase is localized in the perinuclear region of $\mathrm{C}_{2} \mathrm{C}_{12}$ myoblasts but is distributed uniformly throughout the cytoplasm in nonmuscle cells (Wilson et al. 1995). However, the mechanism of the cellspecific distribution of this mRNA is not known.

\section{Perinuclear zipcode binding polypeptide}

We showed that a myotube-specific $42-\mathrm{kDa}$ polypeptide binds to the sTnC mRNA localization signal. The mutation of the double-stranded regions of this localization signal abolished binding to this polypeptide. Another polypeptide of $68 \mathrm{kDa}$ was also found in higher concentrations in myotubes. The presence of muscle-specific trans-acting factor(s) may explain why the sTnC mRNA localization signal exhibited cell specificity. Although the importance of the interaction between the cis-element(s) of mRNA localization and trans-acting factors in mRNA localization is clear, only a few trans-acting factors have been identified to date ( $\mathrm{Pa}-$ lacios and St Johnston 2001). The majority of these factors, like the chicken ZBP1 (Ross et al. 1997) and Drosophila staufen (Ferrandon et al. 1994), are involved in the peripheral localization of mRNAs. The perinuclear localization signals of several mRNAs, for example, c-Fos, c-Myc, vimentin, and $\alpha$-actin, have been identified but little is known about how these signals work. Recent studies have identified a $35-\mathrm{kDa}$ HAX protein as the vimentin mRNA zipcode-binding protein (AlMaghrebi et al. 2002). Judging from the molecular weight and cell specificity of the sTnC mRNA localization-signalbinding protein, it is evidently not similar to HAX1.

In contrast to the peripheral localization, the perinuclear localization may be guided by a simpler RNA-protein interaction. For the mRNA, like the $\beta$-actin that is localized to the periphery of the cell, an elaborate molecular motor and energy is needed to transport the mRNA to its desired distal location. Whereas, for the perinuclear localization, the mRNA may only need to be trapped at the perinuclear site after exiting the nucleus. Therefore, a simple RNA-protein interaction between the zipcode and the $42-\mathrm{kDa}$ polypeptide might suffice to localize the sTnC mRNA at the perinuclear region. The identity of this $42-$ $\mathrm{kDa}$ zipcode-binding polypeptide is still unknown. We are in the process of the affinity purification and subsequent identification of the 42-kDa polypeptide.

\section{MATERIALS AND METHODS}

\section{Cell culture}

Mouse skeletal muscle $\mathrm{C}_{2} \mathrm{C}_{12}$ myoblasts (ATCC CRL1772) were plated on coverslips (25-mm diameter) in a six-well dish or 35$\mathrm{mm}$ cell culture plates. Cells were plated at $\sim 10 \%$ confluency and grown in Dulbecco's modified Eagle's medium (DMEM) (ATCC), supplemented with $10 \%$ fetal bovine serum (FBS) at $37^{\circ} \mathrm{C}$ in the presence of $5 \% \mathrm{CO}_{2}$. After $2 \mathrm{~d}$, the cells were transferred to a differentiation medium containing 5\% horse serum in DMEM and maintained for $2-3 \mathrm{~d}$ at $37^{\circ} \mathrm{C}$ in the presence of $5 \% \mathrm{CO}_{2}$. Under these conditions the proliferating myoblasts differentiated into mononucleated myocytes and small myotubes with two to four nuclei.

\section{DNA probes for mRNA detection}

To examine the cytoplasmic distribution of mRNAs, molecular beacon oligodeoxynucleotide probes were used (Tyagi and Kramer 1996). Each probe was labeled at the $5^{\prime}$ end with a fluorochrome and at the $3^{\prime}$ end with the Dabcyl Quencher. The nucleotide sequence of the probes for $\alpha$-actin, $\beta$-actin, sTnC, sTnI, and the reporter $\beta$-Gal mRNAs were:

5' -cgcagACCGTCCCAGAATCCAACActgcg-3',

5'-cgcgaCATCTTTTCACGGTTGGCCTTtcgcg-3',

$5^{\prime}$-cgctcTCCTCCTCAGACTTCCCTTTgagcg- $3^{\prime}$,

$5^{\prime}$-ccgtgACTCTGCAGTCTGTGGTGACcacgg-3', and

$5^{\prime}$-cgctcCCAGCAGCAGCAGACCATTTgagcg-3', respectively. 
The probes were complementary to nucleotides 511-530, 417-437, $296-315,21-39$, and $1957-1976$ of $\alpha$-actin, $\beta$-actin, sTnC, sTnI, and $\beta$-Gal mRNAs, respectively (accession numbers M12866, X03672, AA656586, AJ242874, and UO2451, respectively). The uppercase letters indicate the nucleotides complementary to the mRNA, and the lowercase letters at the $5^{\prime}$ and $3^{\prime}$ ends are not complementary to the target mRNA and were used for base pairing between the $5^{\prime}$ and $3^{\prime}$ ends. All probes were synthesized by Qiagen Inc.

\section{In situ hybridization and microscopy of cells}

Differentiated myocytes grown on coverslips were washed in $1 \times$ PBS (100 mM Na $\mathrm{HPO}_{4}, 20 \mathrm{mM} \mathrm{K}_{2} \mathrm{HPO}_{4}, 137 \mathrm{mM} \mathrm{NaCl}, 27 \mathrm{mM}$ $\mathrm{KCl}$ at $\mathrm{pH} 7.4$ ) and fixed for $5 \mathrm{~min}$ at $25^{\circ} \mathrm{C}$ in $4 \%$ formaldehyde (Electron Microscopy Sciences), 10\% acetic acid in PBS. After two washes in PBS, cells were permeabilized by treatment with $70 \%$ ethanol overnight at $4^{\circ} \mathrm{C}$. The cells were rehydrated for $5 \mathrm{~min}$ at $25^{\circ} \mathrm{C}$ in $2 \times \mathrm{SSC}(300 \mathrm{mM} \mathrm{NaCl}, 30 \mathrm{mM}$ sodium citrate at $\mathrm{pH} 7.0)$ in $50 \%$ deionized formamide, followed by hybridization overnight at $37^{\circ} \mathrm{C}$ in a $40 \mu \mathrm{L}$ of a mixture containing $2 \times$ SSC, $50 \%$ formamide, $10 \%$ dextran sulfate, $2 \mathrm{mM}$ vanadyl-ribonucleoside complex, $0.02 \%$ RNase-free BSA, $40 \mu \mathrm{g}$ Escherichia coli tRNA, and 30 ng probe. Following hybridization, cells were washed twice for 30 min using $2 \times$ SSC, $50 \%$ formamide at $37^{\circ} \mathrm{C}$, and mounted in PBS with $70 \%$ glycerol for confocal laser scanning microscopy (CLSM) to obtain a series of images. CLSM of the specimen was performed using a Leica confocal microscope equipped with a krypton-argon laser using a $65 \times$ objective lens. Horizontal optical slices at 100 $\mathrm{nm}$ thickness were taken. The images were captured with Leica software, and the pictures of the individual $\mathrm{z}$ slices (averages of four measurements) were converted to TIFF files. The TIFF images were quantified using the Leica TCS Sp2 software.

\section{Vector and plasmid construction}

The complete mouse slow/cardiac troponin C cDNA (GenBank accession no. AA656586) was used to construct the various chimeras. The reporter plasmid pCMV-SPORT- $\beta$-Gal (Invitrogen Life Technology) was modified by removing a 75 -base pair, BamH1/Nhe1 fragment from the $3^{\prime}$ untranslated region of the $\beta$-Gal gene and the polylinker in the vector. In this plasmid the Cytomegalovirus promoter (CMV) drives the constitutive expression of the reporter $\beta$-galactosidase gene fused to SV 40 intron and the polyadenylation signal in mammalian cells.

Constructs A, D, E, and F (Fig. 2) containing various regions of the 3' UTR of sTnC, mRNA, at the BamH1/Nhe1 restriction enzyme site of the reporter plasmid were generated by ligating PCRamplification products of the sTnC-cDNA-containing plasmid.

For constructing A, D, E, and F expression vectors the forward (sense) primers were:

(i) 5' -gataaggatccATGCTGGTCTTGCAC-3' (A),

(ii) 5' -cagtaggatccGTGTCCTTGAACCTTGG-3' (D),

(iii) $5^{\prime}$-atatcggatccAGACCCCGTGGTAGGA-3' (E), and

(iv) 5'-ttttcggatccTTCGGATCCTTGGTGAGC-3', (F);

and the reverse (antisense) primers were:

(v) 5'-gataagctagcGCGTTCCGCAGGACAGG-3' (A),

(vi) $5^{\prime}$-tcctgctagcAGGCCAAGGTTCAAGGAC-3' (D and F), and

(vii) $5^{\prime}$-tggtcgctagcCTCCACACCCTTCATGAA-3' (E).
All sense primers had BamH1 adaptor, and antisense primers had Nhe1 adaptors at their $5^{\prime}$ ends (indicated with lowercase letters) to help in the directional cloning of the $3^{\prime}$ UTR of sTnC mRNA. PCR reactions were carried out in a $50 \mu \mathrm{L}$ volume containing $10 \mathrm{mM}$ Tris- $\mathrm{HCl}$ ( $\mathrm{pH} 9.0$ ), $15 \mathrm{mM} \mathrm{MgCl}, 50 \mathrm{mM} \mathrm{KCl}, 0.08 \%$ Nonidet P-40, $10 \mathrm{mM}$ dNTPs mix, $200 \mathrm{ng}$ of appropriate primers, 5 units of Taq polymerase, and $20 \mathrm{ng}$ of a plasmid containing the sTnC cDNA (IMAGE Consortium accession \#656586). Thirty-five PCR cycles, each at $94^{\circ} \mathrm{C}$ for $3 \mathrm{~min}, 94^{\circ} \mathrm{C}$ for $15 \mathrm{sec}, 50^{\circ} \mathrm{C}$ for $30 \mathrm{sec}$, and $72^{\circ} \mathrm{C}$ for $1 \mathrm{~min}$, followed by a final cycle at $72^{\circ} \mathrm{C}$ for $5 \mathrm{~min}$, were performed to amplify the desired region of the template. The amplified products were purified using a Qiagen PCR purification kit and digested with BamH1 and Nhe1 restriction enzymes. The digested product of the correct size was gel purified using a Qiagen kit, and the fragment was cloned into the BamH1/Nhe1 site of CMV $\beta$-Gal-SPORT vector to create the chimeric $\beta$-Gal expression vector.

Primers (i) and (v), (i) and (vi), (ii) and (v), and (iii) and (vi) were used to prepare constructs A, D, E, and F (Fig. 2) corresponding to the entire $3^{\prime}$ UTR excluding the poly(A) addition signal (nucleotides 515-669), nucleotides 515-630, 611-669, and 561-630 of the 3' UTR of sTnC mRNA, respectively. Other constructs G, H, I, J, K, and B were generated by annealing customsynthesized-complementary oligodeoxynucleotides (Sigma-Aldrich). The sense and antisense sequences were modified such that after annealing, they contained BamHI/NheI compatible $5^{\prime}$ overhangs for ligation with the vector. Both complementary oligomers were suspended in an annealing buffer $(10 \mathrm{mM}$ Tris at $\mathrm{pH}$ 7.5-8.0, $50 \mathrm{mM} \mathrm{NaCl}, 1 \mathrm{mM}$ EDTA) in equimolar concentrations and were heated at $90^{\circ} \mathrm{C}$ for $5 \mathrm{~min}$. The denatured oligomers were ramp cooled to $25^{\circ} \mathrm{C}$ for annealing. The annealed products were cloned as described above. Constructs G, H, I, and J correspond to nucleotides 540-628, 551-615, 551-576, and 576-615, respectively, of the sTnC $3^{\prime}$ UTR.

Construct $\mathrm{B}$ corresponds to nucleotides 1-28 of the sTnC mRNA 5' UTR. For construct C, primers (iv) and (vii) were used to amplify the 5' UTR and the entire sTnC-coding region (nucleotides $1-511$ ) by PCR. The PCR-amplified product was ligated to the BamHI/NheI-digested pCMV- $\beta-G a l$ vector as described above. Construct $\mathrm{K}$ was similar to construct J, but several nucleotides within two double-stranded stems of the 40-nt-long region of the sTnC 3' UTR were replaced by noncomplementary bases by using appropriate mutagenic oligomers during cloning as described for the creation of construct J.

\section{Transfection of cells}

Cells grown on coverslips were maintained in DMEM supplemented with $5 \%$ horse serum for $3 \mathrm{~d}$. At $60 \%-70 \%$ confluence, the cells were washed twice with $1 \times$ PBS before adding the DNAliposome mixture. Approximately $3 \mu \mathrm{g}$ DNA of the various chimeric $\beta$-Gal-sTnC were incubated with $20 \mu \mathrm{g}$ of Lipofectamine reagent in $200 \mu \mathrm{L}$ OPTI-MEM medium (Invitrogen) at $25^{\circ} \mathrm{C}$ for 30 min. The DNA-lipofectamine mixture was diluted to a final volume of $1 \mathrm{~mL}$ with OPTI-MEM medium before being added to the cells. Cells were incubated with the DNA/liposome complexes for $5 \mathrm{~h}$ at $37^{\circ} \mathrm{C}$ in the presence of $5 \% \mathrm{CO}_{2}$; then, an additional $1 \mathrm{~mL}$ of OPTI-MEM was added and incubated for $24 \mathrm{~h}$ at $37^{\circ} \mathrm{C}$ in a $\mathrm{CO}_{2}$ incubator. 


\section{Preparation of cytoplasmic protein extracts}

Extracts were prepared from proliferating myoblasts grown to $\sim 60 \%-80 \%$ confluence. Myotube extracts were prepared from confluent differentiated cells that were maintained in differentiation medium for $5 \mathrm{~d}$. When the cultures attained the desired confluency and properties, cells were rinsed in cold PBS and then scraped off the plate in cold PBS and centrifuged at 13,000 rpm for $2 \mathrm{~min}$. The pellets were resuspended and lysed by repeatedly passing the cell suspension through a 21 -gauge needle in $400-800 \mu \mathrm{L}$ of cytoplasmic extraction buffer (CEB containing $10 \mathrm{mM}$ HEPES at pH 7.5, $3 \mathrm{mM} \mathrm{MgCl}_{2}, 250 \mathrm{mM} \mathrm{KCl}, 5 \%$ glycerol, $0.2 \%$ Nonidet P-40, $1 \mathrm{mM}$ dithiothreitol [DTT], $0.5 \mathrm{mM}$ phenylmethylsulfonyl fluoride, $10 \mu \mathrm{g} / \mathrm{mL}$ leupeptin, $2 \mu \mathrm{g} / \mathrm{mL}$ aprotonin [Sigma-Aldrich]) (Thomson et al. 1999). The lysate was centrifuged at $16,000 \mathrm{~g}$ for $5-10 \mathrm{~min}$ at $4^{\circ} \mathrm{C}$ to remove cell debris. The concentration of proteins in cell extracts was determined after staining with $0.5 \%$ Coomassie Brilliant Blue dye. The samples were then aliquoted and stored in liquid nitrogen.

\section{Synthesis of radiolabeled RNA transcripts}

To produce a template, which yields RNAs containing only sequences of the 40-nt-long wild-type or the mutant localization signal, the DNA template used was generated by annealing custom synthesized complementary strands (Sigma-Aldrich). A T7 promoter sequence with the transcription start site was added to the $5^{\prime}$ end of the sense strand. Radiolabeled RNA transcripts were obtained by in vitro transcription using the RiboMax T7 RNA polymerase (Promega) according to the manufacturer's instructions, with some modifications, using [ $\alpha^{32}$-P]CTP $3000 \mathrm{Ci} / \mathrm{mmol}$. RNA transcripts were recovered using the QIAqick Nucleotide Removal Kit (QIAGEN). The specific activity of RNA was between 1 and $2 \times 10^{6} \mathrm{cpm} / \mathrm{ng}$.

\section{UV cross-linking of RNA and proteins}

Cellular proteins from myoblasts or myotubes $(75 \mu \mathrm{g})$ were incubated with $50 \mathrm{pg}\left(1 \times 10^{5} \mathrm{cpm}\right)$ of $\left[{ }^{32} \mathrm{P}\right]$-labeled RNA, for $15 \mathrm{~min}$ at $4^{\circ} \mathrm{C}$ in a reaction volume of $20 \mu \mathrm{L}$ made up of CEB and $10 \mu \mathrm{g}$ of E. coli tRNA. After incubation, the samples were exposed to UV light at a distance of $\sim 1 \mathrm{~cm}$. The samples were UV irradiated using a mineral light lamp at $6000 \mu \mathrm{W} / \mathrm{cm}^{2}$ (Ultraviolet Products) for 15 min at $4^{\circ} \mathrm{C}$ (Thomson et al. 1999). Subsequently, the mixture was incubated with RNase A (final conc. $1 \mu \mathrm{g} / \mu \mathrm{L}$ ) and 5 units of RNase $\mathrm{T}_{1}$ (Roche Applied Science) at $37^{\circ} \mathrm{C}$ for $20 \mathrm{~min}$. The samples were then boiled for $3 \mathrm{~min}$ in a sodium dodecyl sulphate (SDS) containing sample buffer $(50 \mathrm{mM}$ Tris- $\mathrm{Cl}$ at $\mathrm{pH} 6.8,2 \%$ [w/v] SDS, $0.1 \%[\mathrm{w} / \mathrm{v}$ ] bromophenol blue, $10 \%$ [v/v] glycerol, $100 \mathrm{mM} \mathrm{DTT}$ ) and the cross-linked proteins were separated using $12 \%$ sodium dodecylsulfate polyacrylamide gel electrophoresis (SDS-PAGE), dried, and autoradiographed at $-80^{\circ} \mathrm{C}$ for $20 \mathrm{~h}$ (Laemmli 1970).

\section{Measurement of $\beta$-Gal mRNA and protein levels}

Approximately $3 \times 10^{5}$ cells were transfected with the different chimeric constructs $(\beta-G a l-s T n C)$ plasmid. The cells were cotransfected with a GFP expression vector (Clonetech) to monitor the difference in transfection efficiencies between experiments. The cells were lysed in $400 \mu \mathrm{L}$ of SDS gel-loading buffer $(50 \mathrm{mM}$ Tris-Cl at $\mathrm{pH} 6.8,2 \%[\mathrm{w} / \mathrm{v}]$ SDS, $0.1 \%[\mathrm{w} / \mathrm{v}]$ bromophenol blue, $10 \%$ [v/v] glycerol, $100 \mathrm{mM}$ DTT). The polypeptides were separated by $12 \%$ SDS-PAGE before being used for Western blotting (Ausubel et al. 1994). The nitrocellulose membranes for Western blotting were separately probed with $\beta$-Gal and green fluorescent protein (GFP) antibodies (Sigma-Aldrich) at room temperature for $2 \mathrm{~h}$ in PBS with $2 \%$ nonfat dry milk and $0.2 \%$ Tween 20 . The nitrocellulose membrane was washed with $0.2 \%$ Tween 20 in PBS and further incubated with an alkaline phosphatase conjugated secondary antibody. The antigen-bound antibody was detected with 4-nitroblue tetrazolium chloride and 5bromo-4chloro3 phosphate as previously described (Ausubel et al. 1994). For measurement of mRNA levels, RNA was isolated from approximately $3 \times 10^{5}$ transfected cells. Cells were first washed three times in ice-chilled PBS, and the total cellular RNA was isolated by using the High Pure RNA isolation kit according to manufacturer's instructions (Roche Biochemical). The quality of the RNA samples was examined by $2 \%$ agarose gel electrophoresis. Samples containing equal amounts of RNA were used for measuring specific mRNA levels by RT-PCR. The RNA was first reverse transcribed by using an mRNA-specific antisense primer. The reverse transcription was carried out using $1 \mu \mathrm{g}$ of total RNA in a volume of $25 \mu \mathrm{L}$ containing 200 units of M-MLV-reverse transcriptase (Invitrogen), 0.1 MDTT (dithiothreitol), $10 \mathrm{mM}$ dNTP, $50 \mathrm{mM}$ Tris$\mathrm{HCl}\left(\mathrm{pH} 8.3\right.$ ), $75 \mathrm{mM} \mathrm{KCl}, 3 \mathrm{mM} \mathrm{MgCl}_{2}$, and $100 \mathrm{ng}$ of an mRNA-specific antisense primer. Reverse transcription was performed at $50^{\circ} \mathrm{C}$ for $1 \mathrm{~h}$, after which a $5-\mu \mathrm{L}$ aliquot was used for PCR amplification. The PCR was carried out in a volume of $50 \mu \mathrm{L}$ containing $10 \mathrm{mM}$ Tris- $\mathrm{HCl}$ ( $\mathrm{pH} 9.0$ ), $15 \mathrm{mM} \mathrm{MgCl}_{2}, 50 \mathrm{mM} \mathrm{KCl}$, $0.08 \%$ nonidet-P-40, $10 \mathrm{mM}$ dNTP, and $200 \mathrm{ng}$ of both forward and reverse primers. The antisense (reverse) primers for both RT and PCR steps were 5 '-CCAGACCAATGCCTCCCAGACCGGC and $5^{\prime}$-GGTTCACCAGGGTGTCG for $\beta$-Gal and GFP mRNA, respectively. The sense (forward) primers for the PCR step were 5'-TTGGCACCAAAATCAACGGGACTTT and 5'-TGAGCAAGG GCGAGGAGC for $\beta$-Gal and GFP mRNA, respectively. The amplification was performed using an initial denaturation step at $95^{\circ} \mathrm{C}$ for $15 \mathrm{sec}$, annealing at $50^{\circ} \mathrm{C}$ for $30 \mathrm{sec}$, and elongation at $72^{\circ} \mathrm{C}$ for $30 \mathrm{sec}$. The amplified products of $340 \mathrm{bp}(\beta-\mathrm{Gal})$ and 362 bp (GFP) were analyzed by $2 \%$ agarose gel electrophoresis using 50-bp size markers (Invitrogen). For both sets of primers, the number of PCR cycles that produced a linear dose response was examined. For both $\beta$-Gal and GFP mRNAs, 25-30 cycles were optimal and produced a linear dose response (input RNA) curve of the PCR product.

\section{ACKNOWLEDGMENTS}

This work was supported by a grant from the Natural Sciences and Engineering Research Council of Canada (NSERC). We thank Dr. Richard Mosser for a critical reading of the manuscript and Kheya Bag for her editorial help. Special thanks go to Dr. Michaela Strueder-Kypke for her help with confocal microscopy. K.K.R. and F.M.O. contributed equally in carrying out the experiments presented here.

Received March 7, 2003; accepted December 7, 2004. 


\section{REFERENCES}

Al-Maghrebi, M., Brule, H., Padkina, M., Allen, C., Holmes, W.M., and Zehner, Z. 2002. The 3' untranslated region of human vimentin mRNA interacts with protein complexes containing CEF-1 $\gamma$ and HaAX-1. Nucleic Acids Res. 320: 5017-5028.

Ausubel, F.F., Brent, R., Kingston, R.E., Moore, D.D., Seidman, J.G., Smitz, J.A., and Struhl, K. 1994. Current protocols in molecular biology. Greene and Wiley-Interscience, New York.

Bally-Cuif, L., Schatz, W.J., and Ho, R.K. 1998. Characterization of the zebrafish Orb/CPEB-related RNA binding protein and localization of maternal components in the zebrafish oocyte. Mech. Dev. 77: 31-47.

Bashirullah, A., Cooperstock, R.L., and Lipshitz, H.D. 1998. RNA localization in development. Annu. Rev. Biochem. 67: 335-394.

Bassell, G.J., Zhang, H.L., Byrd, A.L., Femino, A.M., Singer, R.H., Taneza, K.L., Lifshitz, L.M., and Kosik, K.S. 1998. Sorting of $\beta$-actin mRNA and protein to neutrites and growth cones in culture. J. Neurosci. 18: 251-265.

Bermano, G., Shepherd, R.K., Zehner, Z.E., and Hesketh, J.E. 2001. Perinuclear localisation by vimentin $3^{\prime}$ untranslated region requires a 100 nucleotide sequence and intermediate filaments. FEBS Lett. 497: 77-81.

Bishop, J.M. 1987. The molecular genetics of cancer. Science 235: 305311.

Brenner, H.R., Witzemann, V., and Sakmann, B. 1990. Imprinting of acetylcholine receptor messenger RNA accumulation in mammalian neuromuscular synapses. Nature 344: 544-547.

Chartrand, P., Meng, X.-H., Singer, R.H., and Long, R.M. 1999. Structural elements required for the localization of ASH1 mRNA and of a green fluorescent protein reporter particle in vivo. Curr. Biol. 9: 333-336.

Cripe, L., Morris, E., and Fulton, A.B. 1993. Vimentin mRNA location changes during muscle development. Proc. Natl. Acad. Sci. 90: 2724-2728.

Dalgleish, G., Veyrune, J.L., Blanchard, J.M., and Hesketh, J.E. 2001. mRNA localization by a 145 nucleotide region of the c-Fos $3^{\prime}$ untranslated region. J. Biol. Chem. 276: 13593-13599.

Decker, C.J. and Parler, R. 1995. Diversity of cytoplasmic functions for the $3^{\prime}$ untranslated region of eukaryotic transcripts. Curr. Opin. Cell Biol. 7: 386-392.

Deshler, J.O., Highett, M.I., Abramson, T., and Schnapp, B.J. 1998. A highly conserved RNA-binding protein for cytoplasmic mRNA localization in vertebrates. Curr. Biol. 8: 489-496.

Dhoot, G.K., Gell, P.G.H., and Perry, V. 1978. The localization of the different forms of troponin I in skeletal and cardiac muscle cell. Exp. Cell Res. 117: 357-370.

Ding, D. and Lipshitz, H.D. 1993. Localized RNAs and their functions. Bioessays 15: 651-658.

Ferrandon, D., Elphick, L., Nüsslein-Volhard, C., and St Johnston, D. 1994. Staufen protein associates with the $3^{\prime}$ UTR of bicoid mRNA to form particles that move in a microtubule-dependent manner. Cell 79: 1221-1232.

Gallagher, A.R., Cedzich, A., Gretz, N., Somlo, S., and Witzgall, R. 2000. The polycystic kidney disease protein PKD2 interacts with HAX-1 a protein associated with the actin cytoskeleton. Proc. Natl. Acad. Sci. 97: 4017-4022.

Goldman, D. and Staple, J. 1989. Spatial and temporal expression of acetylcholine receptor RNAs in innervated and denervated rat soleus muscle. Neuron 3: 219-228.

Gonzalez, I., Buonomo, S.B., Nasmyth, K., and von Ahsen, U. 1999. ASH1 mRNA localization in yeast involves multiple secondary structural elements and Ash1 protein translation. Curr. Biol. 25: 337-340.

Gonzalez-Reyes, A., Elliot, H., and St Johnston, D. 1995. Polarization of both major body axes in Drosophila by gurken-torpedo signalling. Nature 375: 654-658.

Gu, W., Pan, F., Zhang, H., Bassell, G.J., and Singer, R.H. 2002. A predominantly nuclear protein affecting cytoplasmic localization of $\beta$-actin mRNA in fibroblasts and neurons. J. Cell Biol. 156: 4151.

Hachet, O. and Ephrussi, A. 2004. Splicing of oskar mRNA in the nucleus is coupled to its cytoplasmic localization. Nature 428: 959963.

Hastings, K.E.M. and Emerson Jr., C.P. 1982. cDNA clone analysis of six co-regulated mRNAs encoding muscle contractile proteins. Proc. Natl. Acad. Sci. 79: 1553-1557.

Havin, L., Git, A., Elisha, Z., Oberman, F., Yaniv, K., Schwartz, S.P., Standart, N., and Yisraeli, J.K. 1998. RNA-binding protein conserved in both microtubule- and microfilament-based RNA localization. Genes \& Dev. 12: 1593-1598.

Hesketh, J.E. 1996. Sorting of mRNAs in the cytoplasm: mRNA localization and cytoskeleton. J. Exp. Cell Res. 225: 219-236.

Hill, M.A. and Gunning, P. 1993. $\beta$ And $\gamma$ actin mRNAs are differentially located within myoblasts. J. Cell Biol. 122: 825-832.

Jackson, R. 1993. Cytoplasmic regulation of mRNA function: The importance of 3'-untranslated region. Cell 74: 9-14.

Jansen, R.P. 2001. mRNA localization: Message on the move. Nat. Cell Biol. 4: 247-256.

Kislauskis, E.H., Zhifang, L., Singer, R.H., and Taneja, K.L. 1993. Isoform specific $3^{\prime}$-untranslated sequences sort $\alpha$-cardiac and $\beta$-cytoplasmic actin messenger mRNAs to different cytoplasmic compartments. J. Cell Biol. 123: 165-172.

Kislauskis, E.H., Zhu, X., and Singer, R.H. 1994. A sequence required for intracellular localization of $\beta$-acin messenger RNA also affects cell phenotype. J. Cell Biol. 127: 441-451.

Laemmli, U. 1970. Cleavage of structural proteins during assembly of the head of the bacterophage T4. Nature 227: 680-685.

Lawrence, J.B. and Singer, R.H. 1986. Intracellular localization of messenger RNAs for cytoskeletal proteins. Cell 45: 407-415.

Lipshitz, H.D. and Smibert, C.A. 2000. Mechanisms of RNA localization and translational regulation. Curr. Opin. Genet. Dev. 10: 476488.

Liu, G., Grant, W.M., Persky, D., Latham Jr., V.M., Singer, R.H, and Condeelis, J. 2002. Interactions of elongation factor 1- $\alpha$ with Factin mRNA: Implications for anchoring mRNA in cell protrusions. Mol. Biol. Cell 13: 579-592.

Long, R.M., Singer, R.H., Meng, X.H., Gonzalez, I., Nasmyth, K., and Jansen, R.P. 1997. Mating type switching in yeast controlled by asymmetric localization of ASH1 mRNA. Science 277: 383-387.

Macdonald, P.M. and Kerr, K. 1998. Mutational analysis of an RNA recognition element that mediates localization of bicoid mRNA. Mol. Cell. Biol. 18: 3788-3795.

Manhertz, H.G. and Goody, R.S. 1976. Proteins of contractile system. Annu. Rev. Biochem. 45: 427-465.

Marras, S.A.E., Kramer, F.R., and Tyagi, S. 2002. Efficiencies of fluorescence resonance energy transfer and contact-mediated quenching in oligonucleotide probes. Nucleic Acids Res. 30: e122.

Muntoni, F., Brown, S., Sewry, C., and Patel, K. 2002. Muscle development genes: Their relevance in neuromuscular disorders. $\mathrm{Neu}$ romuscular Disorders 12: 438-446.

Ojala, J., Choudhury, M., and Bag, J. 1998. Uncordinated inhibition of gene expression for muscle proteins by a troponin $\mathrm{T}$ antisense oligodeoxynucleotide. Antisense Nucleic Acid Drug Dev. 8: 237-247.

Oleynikov, Y. and Singer, R.H. 2003. Real-time visualization of ZBPI association with $\beta$-actin mRNA during transcription and localization. Curr. Biol. 13: 199-207.

Palacios, I.M. and St Johnston, D. 2001. Getting the message across: The intracellular localization of mRNAs in higher eukaryotes. Annu. Rev. Cell Dev. Biol. 17: 569-614.

Parmacek, M.S. and Leiden, J.M. 1991. Structure, function and regulation of Troponin C. Circulation 84: 991-1003.

Potter, J.D. and Gergley, J. 1975. The calcium and magnesium binding sites on troponin and their role in the regulation of myofibrillar adenosine triphosphatase. J. Biol. Chem. 250: 4628-4633.

Ross, A.F., Oleynikov, Y., Kislauskis, F.H., Taneja, K.L., and Singer, R.H. 1997. Characterization of a $\beta$-actin mRNA zipcode binding protein. Mol. Cell. Biol. 17: 2158-2165. 
Sanders, J., Brandsma, M., Janssen, G.M.C., Dijk, J., and Moller, W. 1996. Immunofluorescence studies of human fibroblasts demonstrate the presence of the complex of elongation factor- $1 \beta \gamma \delta$ in the endoplasmic reticulum. J. Cell Sci. 109: 1113-1117.

Saunders, C. and Cohen, R.S. 1999. The role of oocyte transcription, the $5^{\prime}$ UTR, and translation repression and derepression in Drosophila gurken mRNA and protein localization. Mol. Cell 3: 43-54.

Silberstein, L., Webster, S.G., Travis, M, and Blau, H.M. 1986. Developmental progression of myosin gene expression in cultured muscle cells. Cell 46: 1075-1081.

Siomi, H. and Dreyfuss, G. 1997. RNA-binding proteins as regulators of gene expression. Curr. Opin. Genet. Dev. 7: 345-353.

Sokol, D.L., Zhang, X., Lu, P., and Gewirtz, A.M. 1998. Real time detection of DNA: RNA hybridization in living cells. Proc. Natl. Acad. Sci. 95: 11538-11543.

St Johnston, D. 1995. The intracellular localization of messenger RNAs. Cell 81: 161-170.

St Johnston, D. and Nüsslein-Volhard, C. 1992. The origin of pattern and polarity in Drosophila embryo. Cell 68: 201-219.

Takizawa, P., Sil, A., Swedlow, J.R., Herskowitz, I., and Vale, R.D. 1997. Actin-dependent localization of an RNA encoding a cell-fate determinant in yeast. Nature 389: 90-93.

Thio, G.L., Ray, R.B., Barcelo, G., and Schupbach, T. 2000. Localiza- tion of gurken RNA in Drosophila oogenesis requires elements in the $5^{\prime}$ and $3^{\prime}$ regions of the transcript. Dev. Biol. 221: 435446.

Thomson, A.M., Rogers, J.T., Walker, C.E., Staton, J.M., and Leedman, P.J. 1999. Optimized RNA gel-shift and UV cross-linking assays for characterization of cytoplasmic RNA-protein interactions. Biotechniques 27: 1032-1040.

Tyagi, S. and Kramer, F.R. 1996. Molecular beacons: Probes that fluoresce upon hybridization. Nat. Biotechnol. 14: 303-308.

Veyrune, J.L., Campbell, G.P., Wiseman, J., Blanchard, J.M., and Hesketh, J.E. 1996. A localization signal in the $3^{\prime}$ untranslated region of c-Myc mRNA targets c-Myc mRNA and $\beta$ globin reporter sequences to the perinuclear cytoplasm and cytoskeletal-bound polysomes. J. Cell Sci. 109: 1185-1194.

Wilson, I.A., Brindle, K.M., and Fulton, A.M. 1995. Differential localization of the mRNA of the $\mathrm{M}$ and $\mathrm{B}$ isoforms of creatine kinase in myoblasts. Biochem. J. 308: 599-605.

Wiseman, J., Glover, L.A., and Hesketh, J.E. 1997. Evidence for a localization signal in the $3^{\prime}$ untranslated region of myosin heavy chain messenger RNA. Cell Biol. Int. 21: 243-248.

Zehner, Z.E., Shepherd, R.K., Gabryszuk, J., Fu, T.-F., Al-Ali, M., and Holmes, W.M. 1997. RNA-protein interactions with the $3^{\prime}$ untranslated region of vimentin mRNA. Nucleic Acids Res. 25: 33623370 . 

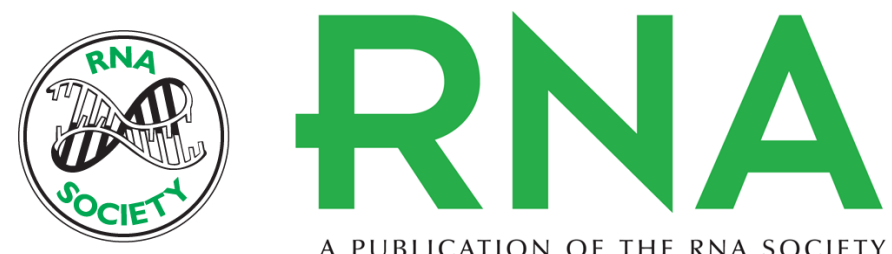

A PUBLICATION OF THE RNA SOCIETY

\section{Perinuclear localization of slow troponin C m RNA in muscle cells is controlled by a cis-element located at its 3' untranslated region}

KISHORE K. REDDY, FERRY M. OITOMEN, GOPAL P. PATEL, et al.

RNA 2005 11: 294-307

References This article cites 54 articles, 20 of which can be accessed free at:

http://rnajournal.cshlp.org/content/11/3/294.full.html\#ref-list-1

License

Email Alerting Receive free email alerts when new articles cite this article - sign up in the box at the Service top right corner of the article or click here. 